\title{
Relationship of Serum Cholesterol and Truncal Body Fat Distribution Among Mexican Americans Is Accentuated by Obesity
}

\author{
A. ROBERTO FRISANCHO, SHELLEY SMITH, AND \\ RACHEL ALBALAK \\ Center for Human Growth and Development, and Department of \\ Anthropology, The University of Michigan, Ann Arbor, Michigan 48109
}

\begin{abstract}
The relationship of body fat distribution to serum cholesterol levels was evaluated in a sample of 3,040 Mexican Americans 18-74 years of age from the Hispanic Health and Nutrition Examination Survey (HHANES) conducted from 1982-1984. Fat distribution was determined by the ratio of trunk to extremity skinfold thicknesses, while the sum of skinfold thicknesses was used as an indicator of total body fat. Results of this study indicate that: 1) Mexican Americans are significantly fatter and have a higher trunk/extremity skinfold ratio than U.S. standards; 2) despite their higher level of total body fat and truncal fat, Mexican Americans have lower serum cholesterol levels than U.S. standards; 3) Mexican American males at the same percentile level of fatness or trunk/ extremity skinfold ratio have significantly higher serum cholesterols than females, despite the fact that females have higher absolute values of fat and truncal fat than males; 4) among Mexican American males the association between truncal fat distribution and hypercholesteremia increases with level of fatness. In other words, in Mexican American males the association of truncal fat distribution with hypercholesteremia is accentuated by obesity. 1994 Wiley-Liss, Inc.
\end{abstract}

According to recent studies the subcutaneous fat of Mexican Americans in the Hispanic Health and Nutrition Examination Survey (HHANES 1982-1984) is greater than in U.S. Whites and Blacks (Kaplowitz et al., 1988; Ryan et al., 1990). Indices of fat distribution also demonstrate a centralized upper body adiposity pattern among Mexican Americans (Kaplowitz et al., 1989; Baumgartner et al., 1990; Haffner et al., 1986). Several investigations have indicated that subjects with excessive fat deposition in the trunk area have a greater incidence of coronary heart disease, increased insulin resistance, hyperinsulinemia, diabetes, hypertension, and hypercholesteremia than individuals with high fat deposition on the extremities (Vague, 1956; Björntorp, 1984; Després et al., 1985; Evans et al., 1984; Hartz et al., 1983; Kalkhoff et al., 1983; Kissebah et al., 1982; Krotkiewski et al., 1983). Similarly, individuals with truncal fat distribution tend to have a higher incidence of ischemic heart disease and related mortality than those with peripheral fat distribution (Kissebah et al.,
1989; Larsson et al., 1984; Lapidus et al., 1984; Stokes et al., 1985; Ducimetiere et al., 1986; Donahue et al., 1987). Studies of Mexican Americans indicate that they have a lower overall mortality rate from cardiovascular diseases than do non-Hispanic Whites (Bouchard et al., 1990). Since there is a relationship between serum cholesterol and risk of cardiovascular disease it is important to know the relationship of body fat distribution to cholesterol levels. Therefore, we have examined the relationship between body fat and fat distribution and serum cholesterol in Mexican Americans from HHANES.

\section{METHODS Sample}

The study is based upon the anthropometric and blood data derived from the

Received January 4, 1993; accepted May 18, 1993.

Address reprint requests to A. Roberto Frisancho, Center for Human Growth and Development, University of Michigan, 300 N. Ingalls, Ann Arbor, MI 48109-0406. 
TABLE 1. General characteristics of Mexican American adults 18-74 years of HHANES

\begin{tabular}{|c|c|c|c|c|}
\hline \multirow[b]{2}{*}{ Variables } & \multicolumn{2}{|c|}{ Males } & \multicolumn{2}{|c|}{ Females } \\
\hline & $\mathrm{N}$ & Mean \pm SD & $\mathrm{N}$ & Mean \pm SD \\
\hline Age (years) & 1,585 & $39.2 \pm 14.6$ & 1.770 & $38.1 \pm 14.4$ \\
\hline Stature $(\mathrm{cm})$ & 1,576 & $170.3 \pm 6.8$ & 1,766 & $157.4 \pm 6.1$ \\
\hline Weight (kg) & 1,579 & $76.0 \pm 14.3$ & 1,766 & $66.0 \pm 14.5$ \\
\hline Body mass index $\left(\mathrm{kg} / \mathrm{m}^{2}\right)$ & 1,576 & $26.1 \pm 4.3$ & 1,766 & $26.7 \pm 5.7$ \\
\hline Triceps skinfolds (mm) & 1,574 & $13.1 \pm 6.8$ & 1,755 & $26.1 \pm 9.5$ \\
\hline Subseapular skinfolds (mm) & 1,572 & $19.5 \pm 9.1$ & 1,755 & $25.0 \pm 11.4$ \\
\hline Suprailiac skinfolds (mm) & 1,575 & $23.9 \pm 11.0$ & 1,756 & $26.5 \pm 10.5$ \\
\hline Calf skinfolds (mm) & 1,570 & $8.8 \pm 5.6$ & 1,747 & $21.2 \pm 9.2$ \\
\hline Sum of skinfolds $(\mathrm{mm})^{1}$ & 1,570 & $32.6 \pm 14.6$ & 1,754 & $51.1 \pm 19.7$ \\
\hline Sum of skinfolds $(\mathrm{mm})^{2}$ & 1,569 & $56.4 \pm 24.0$ & 1,754 & $77.5 \pm 29.1$ \\
\hline Sum of skinfolds $(\mathrm{mm})^{3}$ & 1,563 & $65.2 \pm 28.1$ & 1,745 & $98.6 \pm 35.8$ \\
\hline Trunk/extremity skinfold ratio & 1,570 & $1.6 \pm 0.7$ & 1,754 & $0.9 \pm 0.3$ \\
\hline Trunk/extremity skinfold ratio 5 & 1,569 & $3.6 \pm 1.2$ & 1,754 & $2.0 \pm 0.7$ \\
\hline Trunk/extremity skinfold ratio ${ }^{6}$ & 1,563 & $2.1 \pm 0.7$ & 1,745 & $1.1 \pm 0.3$ \\
\hline Serum cholesterol $(\mu \mathrm{g} / \mathrm{dl})$ & 1,440 & $207.2 \pm 39.9$ & 1,600 & $204.5 \pm 44.0$ \\
\hline Serum cholesterol (mmol/L) & 1,440 & $5.4 \pm 1.0$ & 1,600 & $5.3 \pm 1.1$ \\
\hline
\end{tabular}

'Sum af skinfold thicknesses (mm) - (triceps + subscapular).

${ }^{2}$ Sum of skinfold thicknesses $(\mathrm{mm})=$ (triceps + subscapular + suprailiac skinfolds).

${ }^{3}$ Sum of skinfold thicknesses $(\mathrm{mm})=$ (triceps + subscapular + suprailiac + medial calf skinfolds $)$

${ }^{4}$ Subscapularitriceps ratio $=$ subscapularttriceps skinfold.

Trunk/arm skinfold ratio = (subscapular + suprailiac skinfolds $) /$ (triceps skinfold).

${ }^{6}$ Trumk/extremity skinfold ratio $=$ (subscapular * suprailiac skinfolds)/(triceps + medial calf skinfolds).

TABLE 2. Comparison of average nank order correlations (rho) between indices of body fat distribution and serum cholesterol (mmol/L) by fatness percentile among Mexican American adults 18-74 years of HHANES

\begin{tabular}{|c|c|c|c|c|c|c|}
\hline \multirow{3}{*}{$\begin{array}{l}\text { Fatness } \\
\text { percentile }\end{array}$} & \multicolumn{6}{|c|}{ Cholesterol } \\
\hline & \multicolumn{2}{|c|}{ Subscapula/triceps ${ }^{1}$} & \multicolumn{2}{|c|}{ Trunk/arm ${ }^{2}$} & \multicolumn{2}{|c|}{ Trunk/extremity ${ }^{3}$} \\
\hline & $\mathbf{N}$ & rho & $\mathbf{N}$ & rho & $\mathrm{N}$ & rho \\
\hline \multicolumn{7}{|l|}{ Males } \\
\hline $00.0-9.9$ & 117 & 0.01 & 114 & 0.01 & 109 & 0.16 \\
\hline $10.0-19.9$ & 140 & 0.01 & 143 & 0.01 & 148 & 0.01 \\
\hline $20.0-29.9$ & 136 & 0.01 & 137 & 0.01 & 136 & $0.19^{*}$ \\
\hline $30.0-39.9$ & 144 & 0.11 & 146 & 0.01 & 152 & 0.01 \\
\hline $40.0-49.9$ & 153 & 0.08 & 149 & 0.19 & 139 & 0.08 \\
\hline $50.0-59.9$ & 136 & 0.04 & 135 & 0.01 & 141 & 0.04 \\
\hline $60.0-69.9$ & 141 & 0.08 & 150 & 0.03 & 144 & 0.11 \\
\hline $70.0-79.9$ & 148 & 0.01 & 140 & 0.12 & 143 & $0.19^{*}$ \\
\hline $80.0-89.9$ & 136 & 0.03 & 147 & 0.04 & 144 & 0.11 \\
\hline $90.0-99.9$ & 115 & 0.12 & 109 & $0.31^{* *}$ & 110 & $0.26^{* * *}$ \\
\hline \multicolumn{7}{|l|}{ Females } \\
\hline $00.0-9.9$ & 137 & 0.12 & 139 & 0.11 & 140 & 0.14 \\
\hline $10.0-19.9$ & 163 & 0.11 & 158 & 0.09 & 153 & 0.08 \\
\hline $20.0-29.9$ & 162 & 0.01 & 161 & 0.01 & 158 & 0.01 \\
\hline $30.0-39.9$ & 154 & 0.01 & 159 & 0.01 & 159 & 0.02 \\
\hline $40.0-49.9$ & 168 & 0.01 & 169 & 0.01 & 166 & 0.04 \\
\hline $50.0-59.9$ & 154 & 0.02 & 144 & 0.02 & 153 & 0.07 \\
\hline $60.0-69.9$ & 153 & 0.01 & 163 & 0.11 & 154 & 0.04 \\
\hline $70.0-79.9$ & 158 & 0.01 & 154 & 0.01 & 158 & 0.02 \\
\hline $80.0-89.9$ & 149 & 0.01 & 151 & 0.01 & 153 & 0.03 \\
\hline $90.0-99.9$ & 133 & 0.06 & 134 & 0.01 & 131 & 0.06 \\
\hline
\end{tabular}

${ }_{1}^{1}$ Subscapular/triceps ratio $=$ subscapular/triceps skinfold.

${ }^{2}$ Trunk/arm skinfold ratio = (subscapular + suprailiac skinfolds)/(triceps skinfold).

${ }^{3}$ Trunk/extremity skinfold ratio $=($ subscapular + suprailiac skinfolds $) /($ triceps + medial calf skinfolds $)$.

${ }^{*} P<0.05 ;{ }^{* * *} P<0.01$.

HHANES. HHANES was conducted in order to characterize the health and nutritional status of three Hispanic groups in the United States: Cuban Americans from Dade
County, Florida; Puerto Ricans from the metropolitan New York area; and Mexican Americans from the Southwest (including Arizona, Colorado, New Mexico, Texas, and 
TABLE 3. Mean serum cholesterol (mmollL) by percentile of indices of body fat among Mexican American adults 18-74 years of HHANES

\begin{tabular}{|c|c|c|c|}
\hline \multirow[b]{2}{*}{$\begin{array}{l}\text { Fatness } \\
\text { percentile }\end{array}$} & \multicolumn{3}{|c|}{ Indices of body fat $(\mathrm{mmol} / \mathrm{L})^{4}$} \\
\hline & $\begin{array}{c}\text { Sum of two skinfolds }{ }^{1} \\
\text { Mean } \pm \text { SD }\end{array}$ & $\begin{array}{c}\text { Sum of three skinfolds } \\
\text { Mean } \pm \mathrm{SD}\end{array}$ & $\begin{array}{c}\text { Sum of four skinfolds } \\
\text { Mean } \pm \text { SD }\end{array}$ \\
\hline \multicolumn{4}{|c|}{ Males $(\mathrm{N}=1,366)$} \\
\hline $00.0-9.9$ & $5.18 \pm 1.09$ & $5.13 \pm 0.95$ & $5.14 \pm 0.98$ \\
\hline $10.0-19.9$ & $5.13 \pm 0.95$ & $5.31 \pm 1.06$ & $5.28 \pm 0.97$ \\
\hline $20.0-29.9$ & $5.38+1.02$ & $5.36 \pm 1.11$ & $5.30 \pm 1.10$ \\
\hline $30.0-39.9$ & $5.35 \pm 1.08$ & $5.28 \pm 1.02$ & $5.35 \pm 1.08$ \\
\hline $40.0-49.9$ & $5.36 \pm 1.06$ & $5.36 \pm 1.04$ & $5.33 \pm 1.01$ \\
\hline $50.0-59.9$ & $5.48 \pm 0.86$ & $5.36 \pm 1.00$ & $5.45 \pm 1.02$ \\
\hline $60.0-69.9$ & $5.44 \pm 1.12$ & $5.42 \pm 0.98$ & $5.43 \pm 1.04$ \\
\hline $70.0-79.9$ & $5.49 \pm 1.06$ & $5.39 \pm 0.98$ & $5.46 \pm 0.99$ \\
\hline $80.0-89.9$ & $5.45 \pm 0.89$ & $5.54 \pm 1.05$ & $5.44 \pm 0.98$ \\
\hline $90.0-99.9$ & $5.36 \pm 1.09$ & $5.44 \pm 1.00$ & $5.40 \pm 1.08$ \\
\hline \multicolumn{4}{|c|}{ Females $(\mathrm{N}=1,525)$} \\
\hline $0.00-9.9$ & $5.05 \pm 1.20$ & $5.00 \pm 1.13$ & $5.12 \pm 1.18$ \\
\hline $10.0-19.9$ & $5.11 \pm 1.11$ & $5.13 \pm 1.09$ & $5.05 \pm 1.06$ \\
\hline $20.0-29.9$ & $5.22 \pm 0.98$ & $5.29 \pm 1.16$ & $5.30 \pm 1.10$ \\
\hline $30.0-39.9$ & $5.41 \pm 1.17$ & $5.28 \pm 1.06$ & $5.34 \pm 1.18$ \\
\hline $40.0-49.9$ & $5.27 \pm 1.08$ & $5.37 \pm 1.03$ & $5.31 \pm 1.07$ \\
\hline $50.0-59.9$ & $5.44 \pm 1.18$ & $5.40 \pm 1.26$ & $5.38 \pm 1.18$ \\
\hline $60.0-69.9$ & $5.35 \pm 1.03$ & $5.30 \pm 0.98$ & $5.36 \pm 1.14$ \\
\hline $70.0-79.9$ & $5.35 \pm 1.40$ & $5.36 \pm 1.31$ & $5.40 \pm 1.20$ \\
\hline $80.0-89.9$ & $5.31 \pm 1.11$ & $5.40 \pm 1.16$ & $5.34 \pm 1.20$ \\
\hline $90.0-99.9$ & $5.30 \pm 1.03$ & $5.30 \pm 1.09$ & $5.19 \pm 0.98$ \\
\hline
\end{tabular}

'Sum of skinfold thicknesses $(\mathrm{mm})$ - (triceps + subscapular).

${ }^{2}$ Sim of skinfold thicknesses $(\mathrm{mm})=$ (triceps + subscapular + suprailiac skinfolds)

${ }^{3}$ Sum of skinfold thicknesses $(\mathrm{mm})=$ (triceps + subscapular + suprailiac + medial calf skinfolds).

'The $n$ 's are the same as in Table 2.

$* P<0.05 ; * * P<0.01$

TABLE 4. Mean serum cholesterol (mmol/L) by percentile of indices of fat distribution among Mexican American adults 18-74 years of HHANES

\begin{tabular}{|c|c|c|c|}
\hline \multirow[b]{2}{*}{$\begin{array}{l}\text { Fat distribution } \\
\text { percentile }\end{array}$} & \multicolumn{3}{|c|}{ Indices of fat distribution $(\mathrm{mmol} / \mathrm{L})^{4}$} \\
\hline & $\begin{array}{c}\text { Subscapula/triceps }{ }^{1} \\
\text { Mean } \pm \text { SD }\end{array}$ & $\begin{array}{l}\text { Trunk/arm } \\
\text { Mean } \pm S D\end{array}$ & $\begin{array}{c}\text { Trunk/extremity } \\
\text { Mean } \pm \mathrm{SD}\end{array}$ \\
\hline \multicolumn{4}{|l|}{ Males } \\
\hline $00.0-9.9$ & $5.17 \pm 0.88$ & $5.27 \pm 0.98$ & $5.14 \pm 0.98$ \\
\hline $10.0-19.9$ & $5.29 \pm 0.93$ & $5.25+1.03$ & $5.26 \pm 0.97$ \\
\hline $20.0-29.9$ & $5.26 \pm 1.00$ & $5.25 \pm 0.87$ & $5.12 \pm 1.10$ \\
\hline $30.0-39.9$ & $5.41 \pm 1.06$ & $5.35 \pm 1.00$ & $5.32 \pm 0.98$ \\
\hline $40.0-49.9$ & $5.42 \pm 1.04$ & $5.30 \pm 1.00$ & $5.33 \pm 0.96$ \\
\hline $50.0-59.9$ & $5.42 \pm 0.93$ & $5.55 \pm 1.17$ & $5.50 \pm 1.11$ \\
\hline $60.0-69.9$ & $5.40 \div 1.12$ & $5.47 \pm 1.08$ & $5.55 \pm 1.04^{*}$ \\
\hline $70.0-79.9$ & $5.29+1.02$ & $5.36 \pm 1.12$ & $5.49 \pm 1.12^{*}$ \\
\hline $80.0-89.9$ & $5.43 \pm 1.18$ & $5.46 \pm 1.04$ & $5.46 \pm 1.04^{*}$ \\
\hline $90.0-99.9$ & $5.49 \pm 1.03$ & $5.29 \pm 0.99$ & $5.46 \pm 1.00^{*}$ \\
\hline \multicolumn{4}{|l|}{ Females } \\
\hline $0.00-9.9$ & $5.24 \pm 1.19$ & $5.16 \pm 1.27$ & $5.22 \pm 1.23$ \\
\hline $10.0-19.9$ & $5.39 \pm 1.25$ & $5.25 \pm 0.92$ & $5.06 \pm 1.02$ \\
\hline $20.0-29.9$ & $5.24 \pm 1.17$ & $5.39 \pm 1.31$ & $5.26 \pm 1.07$ \\
\hline $30.0-39.9$ & $5.25 \pm 1.09$ & $5.22 \pm 1.27$ & $5.40 \pm 1.18$ \\
\hline $40.0-49.9$ & $5.13 \pm 1.02$ & $5.31 \pm 1.13$ & $5.25 \pm 1.18$ \\
\hline $50.0-59.9$ & $5.23 \pm 1.14$ & $5.14 \pm 0.96$ & $5.22 \pm 1.00$ \\
\hline $60.0-69.9$ & $5.30+1.14$ & $5.33 \pm 0.97$ & 5.31 上 $1.19^{*}$ \\
\hline $70.0-79.9$ & $5.40 \pm 1.20$ & $5.41+1.19$ & $5.45 \pm 1.12^{*}$ \\
\hline $80.0-89.9$ & $5.35 \pm 1.11$ & $5.28 \pm 1.08$ & $5.38 \pm 1.14^{*}$ \\
\hline $90.0-99.9$ & $5.33 \pm 1.07$ & $5.32 \pm 1.14$ & $5.29 \pm 1.10$ \\
\hline
\end{tabular}

${ }^{1}$ Subscapular/triceps ratio = subscapular/triceps skinfold.

2Trunk/arm skinfold ratio = (subscapular + suprailiac skinfolds $) /($ triceps skinfold $)$.

${ }^{3}$ Trunk/extremity skinfold ratio $=$ (subscapular + suprailiac skinfolds) $/$ (triceps + medial calf skinfolds)

${ }^{4}$ The n's are the same as in Table 2.

$* P<0.05$ 


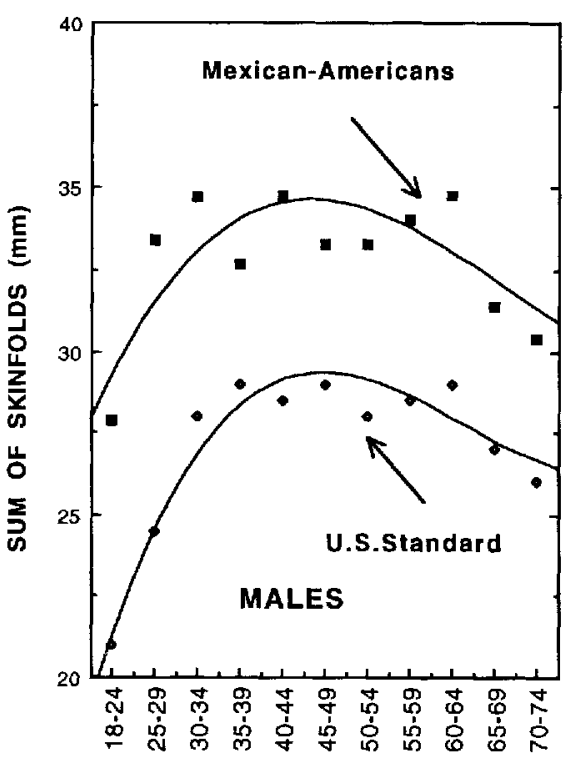

a

AGE (years)

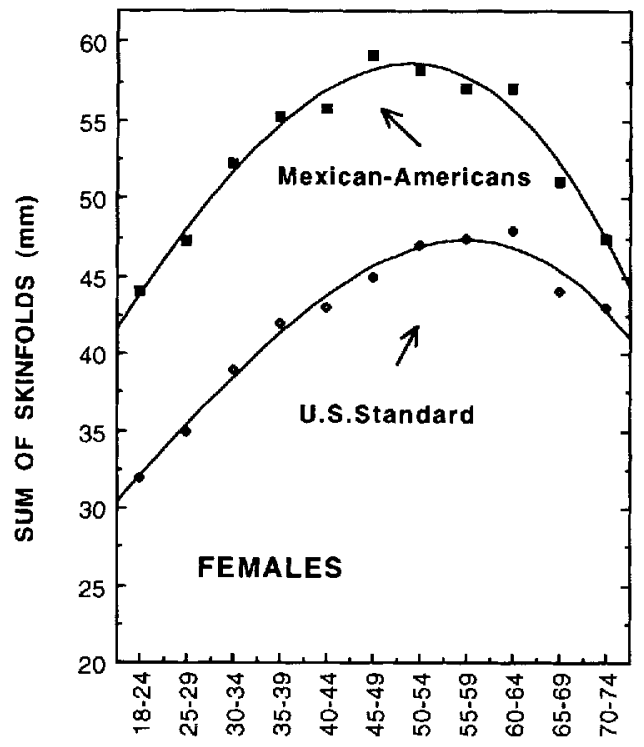

b

AGE (years)

Fig. 1. Median sum of triceps and subscapular skinfold thicknesses of Mexican American adults compared to U.S. Whites (Frisancho, 1990). At all ages Mexican Americans are significantly fatter than U.S. Whites,

California). The sample for the present study is composed of only those identified as Mexican American and excludes all other ethnic groups (i.e., Cubans, Puerto Ricans, American Indians, etc.) included in the HHANES data sets. Age, stature, weight, the triceps, subscapular, suprailiac, and medial calf skinfolds, and serum cholesterols were available for 3,040 Mexican Americans 18-74 years of age. The general characteristics of the data are summarized in Table 1.

\section{Measurements}

Anthropometric data were collected following the same procedures as used in the second National Health and Nutrition Examination Survey (NHANES II-National Center for Health Statistics, 1981). Stature was measured to the nearest $0.1 \mathrm{~mm}$. Weight, including weight of the clothing, was measured to the nearest $0.01 \mathrm{~kg}$. The body mass index (weight $/$ stature, $\mathrm{kg} / \mathrm{m}^{2}$, BMI) was computed. Skinfold thicknesses at the triceps, subscapular, suprailiac, and medial calf sites were measured on the right side with a Lange caliper to the nearest 0.5 $\mathrm{mm}$. The technical errors of measurement and reliability of the anthropometric data for Mexican Americans were similar to those found in the NHANES II (Chumlea et al., 1990).

The medical evaluations included medical history, physical examination, anthropometry, dietary information (24-hour recall and food frequency), laboratory tests, electrocardiograms (ECGs), and radiographs. Blood samples were analyzed by the Clinical Chemistry Division, Center for Environmental Health, Centers for Disease Control.

\section{Analysis}

Fatness. The sum of skinfold thicknesses at given body sites were used as indicators of total body fat. Three indices were derived (Bouchard et al., 1980):

1. Sum of skinfold thicknesses $(\mathrm{mm})=$ (triceps + subscapular skinfold)

2. Sum of skinfold thicknesses $(\mathrm{mm})=$ (triceps + subscapular + suprailiac skinfolds).

3. Sum of skinfold thicknesses $(\mathrm{mm})=$ (triceps + subscapular + suprailiac + medial calf skinfold).

Fat distribution. Three indices of fat distribution were derived: 


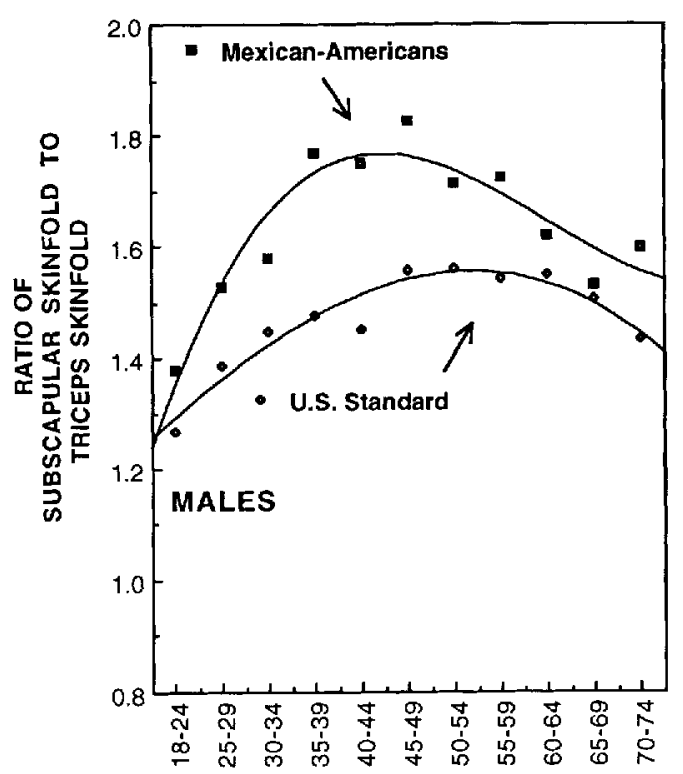

a

AGE (years)

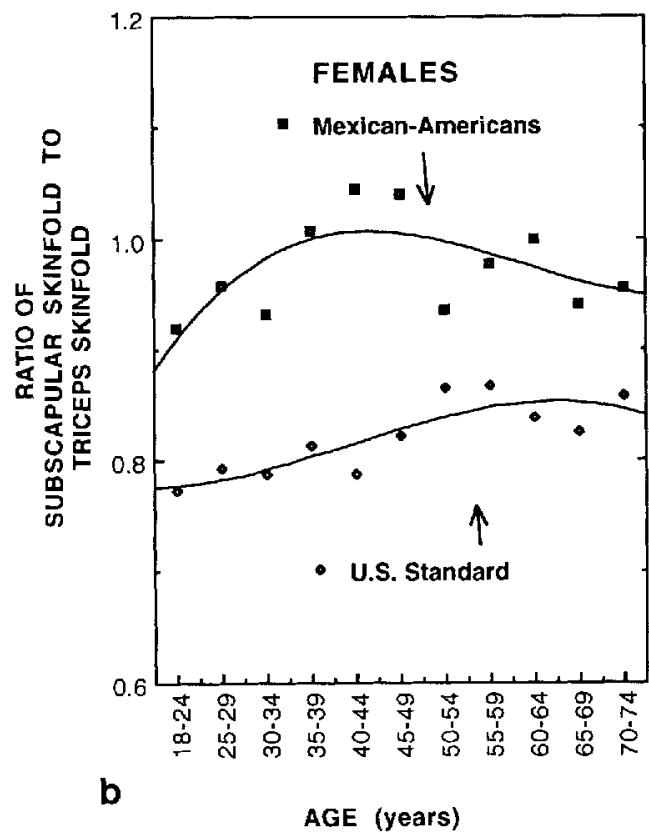

AGE (years)

Fig. 2. Median subscapular-to-triceps skinfold thickness ratio of Mexican American adults compared to U.S. Whites (Frisancho, 1990). Mexican Americans, especially females, have an increased truncal fat accumulation over U.S. Whites.

1. Subscapular/triceps ratio $=$ subscapular skinfold/triceps skinfold.

2. Trunk/arm skinfold ratio $=$ (subscapular + suprailiac skinfold)/(triceps skinfold).

3. Trunk/extremity skinfold ratio $=$ (subscapular + suprailiac skinfold)/(triceps + medial calf skinfold).

Normalization of data. All of the anthropometric dimensions and serum cholesterol concentrations were first transformed to $\log 10$ and then converted into age- and sexspecific standardized $\mathrm{Z}$-scores $(\mathrm{Z}=$ mean value - individual's value/SD).

Percentile levels. Using as reference either the sum of skinfold indices or indices of fat distribution, the samples were classified into 10 age- and sex-specific percentile intervals.

Correlation analysis. Using as reference the three indices of fat distribution, the data were grouped into 10 age- and sex-specific percentile intervals $(1-9,10-19,20-29,30$ $39,40-49,50-59,60-69,70-79,80-89,90-$ 99). Using previously normalized values for each percentile group, the rank order correlation coefficients (rho) between serum cho- lesterol and indices of fat distribution were determined (Table 2).

Mean values. Using as reference either the sum of skinfold indices or the indices of fat distribution, the data were grouped into 10 age- and sex-specific percentile intervals (1-9, 10-19, 20-29, 30-39, 40-49, 50-59, $60-69,70-79,80-89,90-99)$. For each percentile group, means and standard deviations of serum cholesterol were calculated (Tables 3,4). The statistical significance of differences in serum cholesterol was evaluated by analysis of variance using previously normalized values.

Polynomial regressions. To illustrate the relationship of serum cholesterol to either indices of fat distribution or sum of skinfolds, third degree polynomial regressions were calculated for the 10 age- and sex-specific percentile groups.

\section{RESULTS}

As shown in Figures 1 and 2 at every age Mexican Americans are significantly fatter and have a higher subscapular/triceps skinfold ratio than U.S. standards (Frisancho, 1990). However, as illustrated in Figure 3, between 55 and 69 years of age in males and 

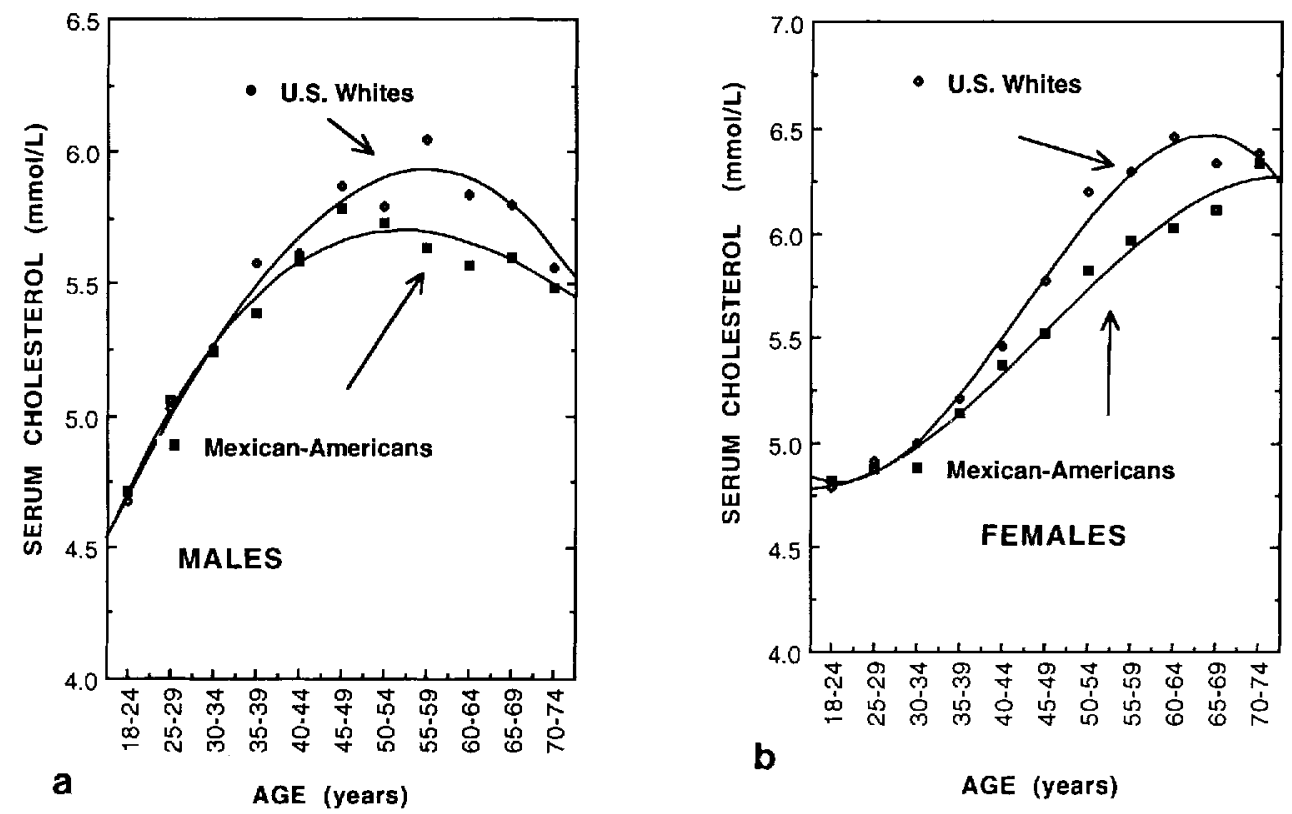

Fig. 3. Mean serum cholesterols (mmol/L) of Mexican American adults compared to U.S. Whites. The lines for Mexican Americans were derived from 3rd degree polynomial regressions using individual data while the dots are the average values for each age group.

between 45 and 65 years in females serum cholesterols of Mexican Americans are significantly lower than those of the U.S. Whites.

Tables 2 and 3 and Figure 4 give the average rank order correlations between fat distribution and serum cholesterol levels in Mexican Americans. It is evident that in males, but not in females, the correlation between serum cholesterol and truncal fat distribution increases with percentile level of fatness.

\section{DISCUSSION}

It is evident that in males, but not in females, the correlation between serum cholesterol and truncal fat distribution increases with percentile level of fatness. These findings suggest that in males a truncal fat distribution accentuates the association between fatness level and serum cholesterol and becomes more evident with increasing levels of obesity. Conversely, it appears that overall leanness protects against the risk of hypercholesteremia associated with truncal fat distribution. It has been estimated that with every increase of $1 \mu \mathrm{g} / \mathrm{dL}$ in serum cholesterol, the risk of cardiovascular disease increases by $1 \%$ (Grundy and Barnett, 1990).
Applying this relationship to the present data, the risk of cardiovascular disease among obese males with truncal fat distribution would be increased by $2 \%$ compared with to those with peripheral fat accumulation. These findings confirm the numerous reports in the literature which indicate that the topography of adipose tissue is associated with metabolic complications which are considered risk factors for cardiovascular diseases such as insulin resistance, hyperinsulinemia, diabetes, hypertension, and hypercholesteremia (Kissebah et al., 1989; Larsson et al., 1984; Lapidus et al., 1984; Stokes et al., 1985; Ducimetiere et al., 1986; Donahue et al., 1987; Després et al., 1990; Fujioka et al., 1987; Ohlson et al., 1985; Peiris et al., 1989; Sparrow et al., 1986).

The lower association between fatness and cholesterol may also be related to the fact that among Mexican Americans the health implications of adiposity do not have the same effect as in White populations. This fact is also compounded by cultural factors that view fatness as a positive rather than a negative trait. In fact, studies among Mexican Americans have demonstrated that the term fat (gordo) is used as an indication 


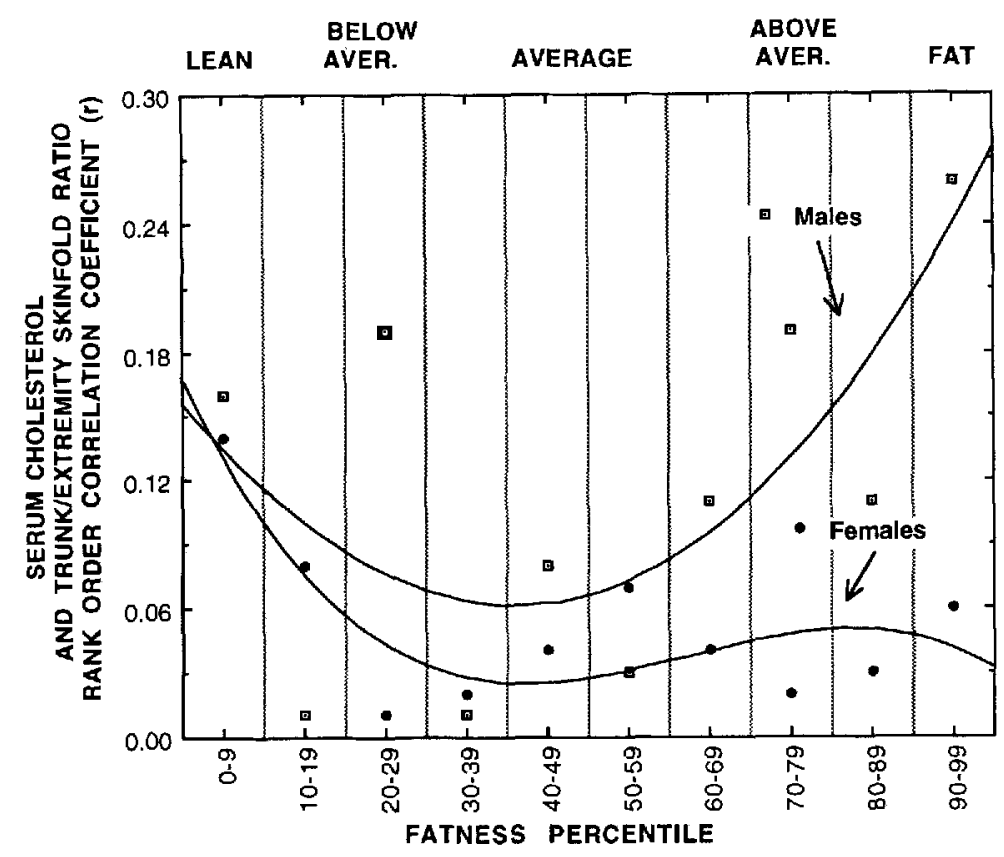

Fig. 4. Rank order correlations between serum cholesterol and trunk/extremity skinfold ratio of Mexican American males and females by percentile category. In males, the relationship between truncal fat accumulation and serum cholesterol is curvilinearly associated with the amount of fatness.

of good health, beauty, and success (Massara, 1989; Rittenbaugh, 1982). For this reason, Mexican Americans use the term gordura mala (bad fatness) when describing fatness that is associated with health risk factors (Rittenbaugh, 1982). It is, therefore, quite possible that among Mexican Americans the association of fatness and cholesterol becomes evident only when the amount of fat is really high and when cultural factors compound this association. However, in Mexican Americans this relationship becomes evident only among the obese males. It should also be noted that since the present analysis was based upon measurements of skinfold thicknesses, the extent to which the present findings reflect an actual effect of visceral fat on cholesterol cannot be determined. It is quite possible that while Mexican Americans may have higher trunk extremity ratios than U.S. standards, they may have lower levels of abdominal visceral fat. In fact, a recent study has demonstrated that measurements of external fatness, such as those derived from skinfolds or from circumferences, are poor indicators of internal body fat distribution (Van Der Kooy et al.,
1993). It is quite possible then that the truncal fat distribution derived from skinfolds used in the present study may not be a good indicator of internal fat among the Mexican Americans. To clarify this issue, more precise measurements of internal body fat such as those derived from computer topography (Després et al., 1991) are needed.

The low serum cholesterols of Mexican Americans compared to U.S. Whites may be related to differences in composition of dietary intakes, differences in amount of exposure time to foods high in cholesterol, or perhaps genetic differences in sensitivity to the effects of high cholesterol. The origin of this difference, however, is beyond the scope of the present analysis.

In summary, unlike Whites, in Mexican Americans the association between truncal fat distribution and serum cholesterol occurs only at high levels of obesity.

\section{LITERATURE CITED}

Baumgartner RN, Roche AF, Guo S, Chumlea WC, and Ryan AS (1990) Fat patterning and centralized obesity in Mexican-American children in the Hispanic 
Health and Nutrition Examination Survey (HHANES 1982-1984). Am. J. Clin. Nutr. 51(suppl):936S-943S.

Björntorp P (1984) Hazards in subgroups of human obesity. Eur. J. Clin. Invest. 14:239-241.

Bouchard C, Demirjian A, and Malina RM (1980) Heritability estimates of somatotype components based upon familial data. Hum. Hered. 30:112-118.

Bouchard C, Bray GA, and Hubbard VS (1990) Basic and clinical aspect of regional fat distribution. Am. J. Clin. Nutr. 52:946-950.

Chumlea WC, Guo S, Kuczmarski RJ, Johnson CL, and Leahy CK (1990) Reliability for anthropometric measurements in the Hispanic Health and Nutrition Examination Survey (HHANES 1982-1984). Am. J. Clin. Nutr. 51(suppl):902S-907S.

Després JP, Allard C, Tremblay A, Talbot J, and Bouchard $\mathrm{C}$ (1985) Evidence for a regional component of body fatness in the association with serum lipids in men and women. Metabolism 34:967-973.

Després JP, Moorjani S, Lupien PJ, Tremblay A, Nadeau A, and Bouchard C (1990) The regional distribution of body fat, plasma lipoproteins, and cardiovascular disease. Arteriosclerosis 10:497-511.

Després JP, Prud'homme D, Pouliot M-C, Tremblay A, and Bouchard C (1991) Estimation of deep abdominal adipose-tissue accumulation from simple anthropometric measurements in men. Am. J. Clin. Nutr. 54: 471-477.

Donahue RP, Abbott RD, Bloom E, Reed DM, and Yano $\mathrm{K}$ (1987) Central obesity and coronary heart disease in men. Lancet 1:822-824.

Ducimetiere P, Richard J, and Cambien F (1986) The pattern of subcutaneous fat distribution in middleaged men and the risk of coronary heart disease: The Paris Prospective Study. Int. J. Obes. 10:229 240.

Evans DJ, Hoffman RG, Kalkhoff RK, and Kissebah AH (1984) Relationship of body fat topography to insulin sensitivity and metabolic profiles in premenopausal women. Metabolism 12:351-357.

Frisancho AR (1990) Anthropometric Standards for the Evaluation of Growth and Nutritional Status. Ann Arbor, MI: University of Michigan Press.

Fujioka S, Matsuzawa Y, Tokunaga K, and Tarui S (1987) Contribution of intra-abdominal fat accumulation to the impairment of glucose and lipid metabolism in human obesity. Metabolism 36:54-59.

Grundy SM, and Barnett JP (1990) Metabolic and health complications of obesity. Disease-a-Month 36 . 645-731.

Haffner SM, Stern MP, Hazudda HP, Pugh J, Patterson JK, and Malina RM (1986) Upper body and centralized adiposity in Mexican American and non-Hispanic whites: Relationship to body mass index and other behavioral and demographic variables. Int. J. Obes. 10:493-502.

Hartz AJ, Rupley DC Jr, Kalkhoff RK, and Rimm AA (1983) Relationship of obesity to diabetes: Influence of obesity level and body fat distribution. Prev. Med. 12: 351-357.

Kalkhoff RK, Hartz AZ, Rupley D, Kissebah AH, and Kelber S (1983) Relationship of body fat distribution to blood pressure, carbohydrate tolerance, and plasma lipids in healthy obese women. J. Lab. Clin. Med. 102: 621-627.

Kaplowitz H, Martorell R, and Mendoza FS (1989) Fatness and fat distribution in Mexican-American chil- dren and youths from the Hispanic Health and Nutrition Examination Survey. Am. J. Hum. Biol. 1:631648 .

Kaplowitz HJ, Wild KA, Mueller WH, Decker M, and Tanner JM (1988) Serial and parent-child changes in components of body fat distribution and fatness in children from the London Iongitudinal Growth Study, age two to eighteen years. Hum. Biol. 60:739758 .

Kissebah AH, Vydelingum N, Murray R, Evans DJ, Hartz AJ, Kalkhoff RK, and Adams PW (1982) Relationship of body fat distribution to metabolic complications of obesity. J. Clin. Endocr. Metab. 54:154-160.

Kissebah AH, Freedman DS, and Peiris AN (1989) Health risks of obesity. Med. Clin. North Am. 73:111138.

Krotkiewski M, Björntorp L, and Smith U (1983) Impact of obesity on metabolism in men and women: Importance of regional adipose tissue distribution. J. Clin. Invest. $72: 1150-1162$.

Lapidus L, Bengtsson C, Icarsson B, Penne RK, Rybo E, and Sjostrom L (1984) Distribution of adipose tissue and risk of cardiovascular disease and death: A 12 year follow-up of participants in the population study of women in Gothenburg, Sweden. Br. Med. J. 289. 1261-1263.

Larsson B, Svardsudd K, Welin L, Wilhemsen L, Bjorntorp $P$, and Tibblin $G$ (1984) Abdominal adipose tissue distribution, obesity and risk of cardiovascular disease and death: 13 year follow-up of participants in the study of men born in 1913. Br. Med. J. 288:14011404 .

Massara EB (1989) Que gordita!. A study of weight among women in a Puerto Rican community. New York: AMS Press, Inc.

National Center for Health Statistics (1981) Plan and operation of the Second National Health and Nutrition Examination Survey, 1976-1980. Vital and Health Statistics Series 1, No. 15

Ohlson LO, Larsson B, Svardsudd K, Welin L, Eriksson H, Wilhelmsen L, Bjorntorp P, and Tibblin G (1985) The influence of body fat distribution on the incidence of diabetes mellitus-13.5 years of follow-up of the participants in the study of men born in 1913. Diabetes 34:1055-1058.

Peiris AN, Sothmann MS, Hennes MI, Lee MB, Wilson CR, Gustafson AB, and Kissebah AH (1989) Relative contribution of obesity and body fat distribution to alterations in glucose insulin homeostasis: Predictive values of selected indices in premenopausal women. Am. J. Clin. Nutr. 49:758-764.

Rittenbaugh C (1982) Obesity as a culture-bound syndrome. Cult. Med. Psychiatry 6:347-361.

Ryan AS, Martinez GA, Baumgartner RN, Roche AF, Guo S, Chumlea WC, and Kuczmarski RJ (1990) Median skinfold thickness distributions and fat-wave patterns in Mexican-American children from the Hispanic Health and Nutrition Examination Survey (HHANES 1982-1984). Am. J. Clin. Nutr. 5l(suppl): 925S-935S.

Sparrow D, Borkan GA, Gerzof SG, Wisniewski C, and Silbert CK (1986) Relationship of body fat distribution to glucose tolerance. Results of computed tomography in male participants of the normative aging study. Diabetes 35:411-415.

Stokes J III, Garrison RI, and Kannel WB (1985) The independent contributions of various indices of obesity to the 22-year incidence of coronary heart disease: 
The Framingham Heart Study. In J Vague, P Bjorntorp, B Guy-Grand, M Rebuffe-Scrive, and P Vague (eds.): Metabolic Complications of Human Obesities. Amsterdam: Elsevier, pp. 49-57.

Vague J (1956) The degree of masculine differentiation of obesities: A factor determining predisposition to diabetes, atherosclerosis, gout, and uric calculous disease. Am. J. Clin. Nutr. 4:20-34.

van der Kooy K, Leenen R, Seidell JC, Deurenberg P, Droop A, Bakker CJG (1993) Waist-hip ratio is a poor predictor of changes in visceral fat. Am. J. Clin. Nutr. 57:327-333. 